\title{
INTERCROPPING OF CABBAGE WITH MAIZE
}

\author{
M.M. Khanum ${ }^{1^{*}}$, M.M. Bazzaz ${ }^{2}$, B. Ahmed ${ }^{3}$, M.S. Huda ${ }^{4}$ and M.A. Hossain ${ }^{5}$ \\ ${ }^{1}$ Scientific Officer, Agricultural Research Station, BARI, Rajbari, Dinajpur-5200 \\ ${ }^{2}$ Senior Scientific Officer, Bangladesh Wheat and Maize Research Institute, Nasipur, Dinajpur-5200 \\ ${ }^{3}$ Scientific Officer, Plant Physiology Division, Station, BARI, Gazipur-1701 \\ ${ }^{4,5}$ Senior Scientific Officer, Agricultural Research Station, BARI, Rajbari, Dinajpur-5200 \\ Corresponding E-mail: mahbuba.bari27@gmail.com \\ (Received: 19 September 2019, Accepted: 27 November 2019)
}

Keyword: Intercropping, maize, cabbage, cereal, yield, cost-benefit

\begin{abstract}
The experiment was carried out at the research field of Agricultural Research Station, Rajbari, Dinajpur (Latitude: 25.63544, Longitude: 88.65144) during rabi season of 2016-2017 and 2017-18 under AEZ-1 to find out the suitable crop combination for higher productivity and economic return. Five different treatments were employed in the study viz. $\mathrm{T}_{1}=$ Sole maize $(60 \mathrm{~cm} \times 420 \mathrm{~cm}), \mathrm{T}_{2}=$ Maize planting $(75 \mathrm{~cm} 4 \mathrm{x} 25 \mathrm{~cm})$ +1 row cabbage $(50 \mathrm{~cm} 450 \mathrm{~cm}) \mathrm{T}_{3}=$ Maize paired row $(150 \mathrm{~cm} / 37.5 \mathrm{~cm} \mathrm{x}$ $25 \mathrm{~cm})+2$ rows cabbage $(50 \mathrm{~cm} \times 450 \mathrm{~cm}) \mathrm{T}_{4}=$ Maize planting $(60 \mathrm{~cm}$ $\mathrm{x} 420 \mathrm{~cm})+1$ row cabbage $(60 \mathrm{~cm} \times 450 \mathrm{~cm}), \mathrm{T}_{5}=$ Maize paired row $(120 \mathrm{~cm} / 30 \mathrm{~cm} 4 \times 20 \mathrm{~cm})+2$ rows cabbage $(60 \mathrm{~cm} \times 50 \mathrm{~cm})$ were evaluated. Maize grain yield in intercropped combination varied from 6.60-9.23 t ha ${ }^{-1}$. But the highest maize yield was recorded in Maize planting $(60 \mathrm{~cm} \times 20 \mathrm{~cm})+1$ row cabbage $(60 \mathrm{~cm} \times 50 \mathrm{~cm})$ followed by that in maize paired row $(150 / 37.5 \mathrm{~cm} Ч 25 \mathrm{~cm})+2$ rows cabbage $(50 \mathrm{~cm}$ $\mathrm{x} 450 \mathrm{~cm})$, while the highest cabbage yield was recorded in maize planting $(60 \mathrm{~cm} \times 20 \mathrm{~cm})+1$ row cabbage $(60 \mathrm{~cm} \times 50 \mathrm{~cm})$ between maize. The highest maize equivalent yield was also obtained in maize planting $(60 \mathrm{~cm}$ $\mathrm{x} 20 \mathrm{~cm})+1$ row cabbage $(60 \mathrm{~cm} \times 50 \mathrm{~cm})$ followed by that in maize paired row $(150 / 37.5 \mathrm{~cm} \times 25 \mathrm{~cm})+2$ rows cabbage $(50 \mathrm{~cm} \times 50 \mathrm{~cm})$. The highest gross return, gross margin and $\mathrm{BCR}$ were obtained in maize planting $(60 \mathrm{~cm}$ บ $20 \mathrm{~cm})+1$ row cabbage $(60 \mathrm{~cm} \times 50 \mathrm{~cm})$ followed by that in maize paired row $(150 / 37.5 \mathrm{~cm} \times 25 \mathrm{~cm})+2$ rows cabbage $(50 \mathrm{~cm}$ $\mathrm{x} 50 \mathrm{~cm})$ and the lowest in sole sowing of maize. The overall results indicated that among the intercrop combinations maize planting $(60 \mathrm{~cm} \mathrm{x}$ $20 \mathrm{~cm})+1$ row cabbage $(60 \mathrm{~cm} \times 50 \mathrm{~cm})$ and maize paired row $(150 / 37.5 \mathrm{~cm} \times 25 \mathrm{~cm})+2$ rows cabbage $(50 \mathrm{~cm} \times 50 \mathrm{~cm})$ were found suitable for total productivity and economic return of the system.
\end{abstract}

\section{Introduction}

Intercropping may be defined as the cultivation of two or more crops at the same time in the same field (Ouma and Jeruto, 2010). Intercropping offers a possible solution to raise productivity through temporal intensification in a country like Bangladesh where the possibility of bringing more land under cultivation is limited. Yield advantages through intercropping have been reported by many workers (Willey, 1979). The advantages is often attributed to the fact that different crops complement each other and make better use of resources when grown together rather than separately (Ahmed et al., 2018). Besides, intercropping also acts as insurance for resource poor farmers if one crop fails, they get some yield of another crop (Islam et al., 2014). Maize (Zea mays) is a versatile photo insensitive crop which can give high yield relatively in a shorter period of time due to its unique photosynthetic mechanism as $\mathrm{C}_{4}$ plant (Hatch 
Khanum et al.

and Slack, 1998). Maize is the third important cereal crop in Bangladesh (BBS, 2015). The area coverage under maize in Dinajpur is expanding rapidly instead of wheat. Due to development of some potential hybrid maize and its availability in this region, farmers tend to shift their cultivation with maize crop in Rabi season (Shaheenuzzaman et al., 2015). In addition to that, favorable agro-climatic conditions have made this crop suitable for greater adoption in winter season in Dinajpur region as well as in the country. Being row and spaced crop, some short duration vegetables may have access to grow with maize as intercrop for extra quick cash generation without hampering maize yield. Innovations in MaizeLegume intercropping allow farmers to grow a wide range of food legumes as understory intercrops with Maize. Maize can be planted at its recommended population, but every other row is shifted to provide a wider alternate inter row to the legume or strip-cropped by lowering Maize population but maintaining similar yields (Ahmed et al., 2008). Growing of short duration vegetables specially cabbage as intercrop with maize in between row may offer considerable yield advantage over sole cropping due to efficient utilization of growth resources (Talukder et al., 2016). Cabbage (Brassica oleracea L.var. capitata f.), is an important cole crop, belonging to family cruciferae, is rich in phyto nutrients and antioxidants. Mixed or intercropping can increase total productivity of land through maximum utilization of natural resources (Thayamini et al., 2010). Higher total productivity per unit area in intercropping is achieved over sole cropping (Boras et al., 2006). Intercropping practices lead to more monetary return and better utilization of land and inputs (Quayyum et al., 1985). Regarding this views, an attempt was undertaken to get maximum benefit from intercropping by optimizing plant population of maize and cabbage.

\section{Materials and Methods}

The experiment was conducted in the research field of Agricultural Research Station, Rajbari, Dinajpur (Latitude: 25.63544, Longitude: 88.65144) during rabi season of 2016-2017 and 2017-18. The experiment was laid out in randomized complete block $(\mathrm{RCB})$ design with three replications. The unit plot size was $6 \mathrm{~m} \times$ $4 \mathrm{~m}$. Five different treatments were employed in the study viz. $\mathrm{T}_{1}=$ Sole maize $(60 \mathrm{~cm} \times 420 \mathrm{~cm}), \mathrm{T}_{2}=$ Maize planting $(75 \mathrm{~cm} \times 25 \mathrm{~cm})+1$ row cabbage $(50 \mathrm{~cm} \times$ $50 \mathrm{~cm}), \mathrm{T}_{3}=$ Maize paired row $(150 \mathrm{~cm} / 37.5 \mathrm{~cm} \times 25 \mathrm{~cm})+2$ rows cabbage $(50 \mathrm{~cm} \times 50 \mathrm{~cm}), \mathrm{T}_{4}=$ Maize planting $(60 \mathrm{~cm} 420 \mathrm{~cm})+1$ row cabbage $(60 \mathrm{~cm} \times$ $50 \mathrm{~cm}), T_{5}=$ Maize paired row $(120 \mathrm{~cm} / 30 \mathrm{~cm} \times 20 \mathrm{~cm})+2$ rows cabbage $(60 \mathrm{~cm} \mathrm{x}$ $50 \mathrm{~cm})$. The land of the experimental plot was prepared with a power tiller by ploughing and cross ploughing followed by laddering and the soil was brought into good tilth. Fertilizers were applied @ 260-72-148-48-4-2 kg ha-1 N-P-K-S-Zn-B in the form of Urea-TSP-MOP-Gypsum-ZnSo ${ }_{4}$-Boric acid for both the sole maize and intercrop combinations. One third of urea and full amount of other fertilizers were applied at final land preparation. Remaining urea was applied at 30 and 60 DAS in two equal splits. Maize (BARI hybrid bhutta-9) was sown on November 02-04 during the conducting years and cabbage (BARI Badhacopy-1) was sown on November 12-14 during the consecutive years. Two irrigations were provided after top dressing of urea. Earthing up and other intercultural operations were done when required. Other plant protection measures were taken when required. Cabbage was harvested on January 10-12 and the maize on April 1013 respectively during the consecutive years. Yield contributing characters of cabbage and maize were measured from ten randomly selected plants of the sampling area of each treatment avoiding border plants. Maize grain yield and cabbage yield were measured from the whole plot and then calculated per hectare basis maintaining standard moisture content. The relative yield was 


\section{Intercropping of Cabbage With Maize}

119

obtained by dividing the intercrop yield of a crop with the respective sole crop yield of that crop using the formula (Dewit and Vander Bergh, 1965).

The relative yield of a crop = Yield of component crops / Yield of sole crop Maize equivalent yield was computed by converting yield of intercrops on the basis of prevailing market price of individual crop following the formula of Bandyopadhyay (1984) as given below:

Maize equivalent yield $=$ Yim $+($ Yic $\times \mathrm{Pc}) / \mathrm{Pm}$

Where, Yim $=$ Yield of intercrop maize, Yic $=$ Yield of intercrop cabbage, Pm $=$ Market price of maize and $\mathrm{Pc}=$ Market price of cabbage.

Collected data were statistically analyzed by using MSTAT software packages and mean differences for each character were compared by Least Significant Difference (LSD) test (Gomez and Gomez, 1984).

\section{Results and Discussion}

Effect on yield and yield components of maize

Yield and yield contributing characters of intercropped maize were statistically significant (Table 1). The highest plant height $(273.13 \mathrm{~cm})$ was recorded from sole maize and the lowest plant height $(244.28 \mathrm{~cm})$ was obtained from Maize paired row $(120 \mathrm{~cm} / 30 \mathrm{~cm} \times 20 \mathrm{~cm})+2$ rows cabbage $(60 \mathrm{~cm} \times 50 \mathrm{~cm})$ intercropping combination. The highest number of grains $\mathrm{cob}^{-1}(579.06)$ was recorded from sole maize plot and the lowest number of grains $\operatorname{cob}^{-1}$ (453.27) was found in Maize paired row $(120 \mathrm{~cm} / 30 \mathrm{~cm} \times 20 \mathrm{~cm})+2$ rows cabbage $(60 \mathrm{~cm} \times 50 \mathrm{~cm})$ intercropping combination. The same trend was observed in case of 1000 - grain weight and it was ranged from 236.73- $285.53 \mathrm{~g}$ in different treatments. The highest 1000grain weight $(285.53 \mathrm{~g})$ was recorded from sole maize and the lowest 1000 grain weight $(236.73)$ was obtained from Maize paired row $(120 \mathrm{~cm} / 30 \mathrm{~cm} \times 20 \mathrm{~cm})$ +2 rows cabbage $(60 \mathrm{~cm} \times 50 \mathrm{~cm})$ intercropping combination. The highest grain yield (9.11 $\mathrm{t} \mathrm{ha}^{-1}$ ) was recorded from sole maize, which could be due to higher no. of grains $\mathrm{cob}^{-1}$ and 1000- grain weight. The grain yield of maize in intercropped combination varied from 6.60-9.23 $\mathrm{t} \mathrm{ha}^{-1}$. The yield data indicated that due crop competition in intercropping yield loss of maize was observed.

\section{Effect of intercrops}

The intercrop yield of cabbage was influenced significantly by different intercropping combinations (Table 2). The highest cabbage yield $\left(50.04 \mathrm{t} \mathrm{ha}^{-1}\right)$ was recorded from Maize planting $(60 \mathrm{~cm} \times 20 \mathrm{~cm})+1$ row cabbage $(60 \mathrm{~cm} \times 50 \mathrm{~cm})$ intercropping combination followed by Maize paired row $(150 \mathrm{~cm} / 37.5 \mathrm{~cm} \times$ $25 \mathrm{~cm})+2$ rows cabbage $(50 \mathrm{~cm} \times 50 \mathrm{~cm})$ combination $\left.(46.97 \mathrm{t} \mathrm{ha})^{-1}\right)$. The lowest yield was obtained from Maize planting $(75 \mathrm{~cm} \times 25 \mathrm{~cm})+1$ row cabbage $(50 \mathrm{~cm} \times 50 \mathrm{~cm})$ intercropping combination $(41.41 \mathrm{t} \mathrm{ha-1})$.

\section{Maize equivalent yield}

Maize as wider spaced plant offers some component crops to grow together without economic loss sacrificing small maize yield with greater total production in respect of land and time. This practice offered considerable yield advantages and higher economic return over sole cropping because of its efficient utilization of growth resources (Faruque et al., 1996). All the intercropped combinations showed higher maize equivalent yield than sole maize in all cases. Among the treatments, the highest maize equivalent yield $\left(25.50 \mathrm{t} \mathrm{ha}^{-1}\right)$ was obtained from Maize planting $(60 \mathrm{~cm} \times 20 \mathrm{~cm})+1$ row cabbage $(60 \mathrm{~cm} \times 50 \mathrm{~cm})$ followed by that of maize paired row $(150 / 37.5 \mathrm{~cm} \times 25 \mathrm{~cm})+2$ rows cabbage $(50 \mathrm{~cm} \times 50 \mathrm{~cm})$ intercrop combination in the both years (Table 2). The lowest maize equivalent 
Khanum et al.

yield $\left(20.40 \mathrm{t} \mathrm{ha}^{-1}\right)$ was obtained from Maize paired row $(120 \mathrm{~cm} / 30 \mathrm{~cm} \times 20 \mathrm{~cm})$

+2 rows cabbage $(60 \mathrm{~cm} \times 50 \mathrm{~cm})$ intercrop combination.

\section{Cost and return analysis}

The cost and return analysis of sole and intercropping of maize and cabbage are presented in Table 3. Higher gross return was obtained from all intercrop combinations than sole crop. The result revealed that the highest gross return (Tk. $382500 \mathrm{ha}^{-1}$ ) and gross margin (Tk. $298270 \mathrm{ha}^{-1}$ ) were obtained in maize planting $(60 \mathrm{~cm}$ Ч $20 \mathrm{~cm})+1$ row cabbage $(60 \mathrm{~cm} \times 50 \mathrm{~cm})$, followed by maize paired row $(150 / 37.5 \mathrm{~cm} 425 \mathrm{~cm})+2$ rows cabbage $(50 \mathrm{~cm} \times 50 \mathrm{~cm})$. The lowest gross return and gross margin were obtained from sole maize. The highest benefit cost ratio (4.54) was also obtained from maize planting $(60 \mathrm{~cm} 420 \mathrm{~cm})$ +1 row cabbage $(60 \mathrm{~cm} \times 50 \mathrm{~cm})$ followed by that of maize paired row $(150 / 30 \mathrm{~cm}$ บ $25 \mathrm{~cm})+2$ rows cabbage $(50 \mathrm{~cm} \times 50 \mathrm{~cm})$ and the lowest in sole maize (2.55).

Table 1. Yield and yield contributing characters of maize and yield of cabbage underinter cropping situation at ARS, Rajbari, Dinajpur (Pooled data of 2 years)

\begin{tabular}{|c|c|c|c|c|c|}
\hline \multirow[b]{2}{*}{ Treatments } & \multirow{2}{*}{$\begin{array}{l}\text { Plant height } \\
\text { (cm) }\end{array}$} & \multirow{2}{*}{$\begin{array}{l}\text { Grains cob } \\
\text { (no.) }\end{array}$} & \multirow{2}{*}{$\begin{array}{l}\text { 1000-grain } \\
\text { wt.(g) }\end{array}$} & \multicolumn{2}{|c|}{ Yield (t ha-1) } \\
\hline & & & & Maize & Cabbage \\
\hline $\mathrm{T}_{1}$ & 273.15 & 558.13 & 285.53 & 9.23 & - \\
\hline $\mathrm{T}_{2}$ & 269.40 & 579.06 & 266.80 & 6.69 & 46.32 \\
\hline $\mathrm{T}_{3}$ & 251.04 & 532.33 & 265.60 & 7.82 & 46.97 \\
\hline $\mathrm{T}_{4}$ & 270.43 & 570.06 & 270.80 & 8.82 & 50.04 \\
\hline $\mathrm{T}_{5}$ & 244.28 & 453.27 & 236.73 & 6.60 & 41.41 \\
\hline CV (\%) & 3.24 & 5.13 & 3.25 & 3.56 & 5.44 \\
\hline $\operatorname{LSD}_{(0.05)}$ & 13.59 & 52.04 & 13.79 & 13.17 & 5.04 \\
\hline $\begin{array}{l}\mathrm{T}_{1}=\text { Sole } \\
(50 \mathrm{~cm} \times 50 \mathrm{~cm} \\
50 \mathrm{~cm}), \mathrm{T}_{4}= \\
\text { row }(120 \mathrm{~cm} / 3\end{array}$ & $\begin{array}{l}e \quad(60 \mathrm{~cm} \times \\
\mathrm{T}_{3}=\text { Maize }\end{array}$ & ), $\quad \mathrm{T}_{2}=$ Maiz & planting & $\begin{array}{l}25 \mathrm{~cm}) \\
2 \text { rows } \\
<50 \mathrm{~cm})\end{array}$ & $\begin{array}{l}\text { w cabbag } \\
\text { e }(50 \mathrm{~cm}> \\
\text { laize paire }\end{array}$ \\
\hline
\end{tabular}

Table 2. Maize grain yield, Cabbage yield, maize relative and equivalent yield influenced by intercropping with cabbage at ARS, Rajbari, Dinajpur

\begin{tabular}{c|c|c|c|c}
\hline Treatments & $\begin{array}{c}\text { Maize grain } \\
\text { yield } \\
\left(\mathrm{t} \mathrm{ha}^{-1}\right)\end{array}$ & $\begin{array}{c}\text { Cabbage yield } \\
\left(\mathrm{t} \mathrm{ha} \mathrm{h}^{-1}\right)\end{array}$ & $\begin{array}{c}\text { Relative yield of } \\
\text { maize } \\
\left(\mathrm{t} \mathrm{ha} \mathrm{h}^{-1}\right)\end{array}$ & $\begin{array}{c}\text { Maize equivalent } \\
\text { yield }\left(\mathrm{t} \mathrm{ha} \mathrm{h}^{-1}\right)\end{array}$ \\
\hline $\mathrm{T}_{1}$ & 9.23 & - & - & 9.23 \\
$\mathrm{~T}_{2}$ & 6.69 & 46.32 & 0.72 & 22.13 \\
$\mathrm{~T}_{3}$ & 7.82 & 46.97 & 0.85 & 23.48 \\
$\mathrm{~T}_{4}$ & 8.82 & 50.04 & 0.95 & 25.5 \\
$\mathrm{~T}_{5}$ & 6.60 & 41.41 & 0.71 & 20.40 \\
\hline
\end{tabular}

$\mathrm{T}_{1}=$ Sole maize $(60 \mathrm{~cm} \times 20 \mathrm{~cm}), \mathrm{T}_{2}=$ Maize planting $(75 \mathrm{~cm} \times 25 \mathrm{~cm})+1$ row cabbage $(50 \mathrm{~cm} \times$ $50 \mathrm{~cm}), \mathrm{T}_{3}=$ Maize paired row $(150 \mathrm{~cm} / 37.5 \mathrm{~cm} \times 25 \mathrm{~cm})+2$ rows cabbage $(50 \mathrm{~cm} \times 50 \mathrm{~cm})$, $\mathrm{T}_{4}=$ Maize planting $(60 \mathrm{~cm} \times 20 \mathrm{~cm})+1$ row cabbage $(60 \mathrm{~cm} \times 50 \mathrm{~cm}), \mathrm{T}_{5}=$ Maize paired row $(120 \mathrm{~cm} / 30 \mathrm{~cm} \times 20 \mathrm{~cm})+2$ rows cabbage $(60 \mathrm{~cm} \times 50 \mathrm{~cm})$.

Table 3. Cost and return analysis of maize and cabbage under sole and intercropping situations (Average of two years) 


\begin{tabular}{c|c|c|c|c}
\hline Treatments & $\begin{array}{c}\text { Gross return } \\
(\text { Tk. ha }\end{array}$ & $\begin{array}{c}\text { Total } \\
\text { Variable Cost } \\
\left(\text { Tk. ha }{ }^{-1}\right)\end{array}$ & $\begin{array}{c}\text { Gross margin } \\
\left(\text { Tk. ha }^{-1}\right)\end{array}$ & BCR \\
\hline $\mathrm{T}_{1}$ & 138450 & 54230 & 84220 & 2.55 \\
$\mathrm{~T}_{2}$ & 331950 & 84230 & 247720 & 3.94 \\
$\mathrm{~T}_{3}$ & 352150 & 85457 & 266693 & 4.12 \\
$\mathrm{~T}_{4}$ & 382500 & 84230 & 298270 & 4.54 \\
$\mathrm{~T}_{5}$ & 306050 & 87251 & 218799 & 3.50 \\
\hline
\end{tabular}

Market price: Maize $15 \mathrm{Tk} . \mathrm{kg}^{-1}$, Cabbage $5 \mathrm{Tk} . \mathrm{kg}^{-1}$

\section{Conclusion}

The results revealed that the highest yield of maize was obtained in sole cropping of component crops. Under intercropping, the highest maize yield was recorded in Maize planting $(60 \mathrm{~cm} \times 20 \mathrm{~cm})+1$ row cabbage $(60 \mathrm{~cm} \times 50 \mathrm{~cm})$ followed by that of maize paired row $(150 / 37.5 \mathrm{~cm} \times 25 \mathrm{~cm})+2$ rows cabbage $(50 \mathrm{~cm} \times 50 \mathrm{~cm})$, while the highest cabbage yield was recorded in maize planting $(60 \mathrm{~cm}$ 4 $20 \mathrm{~cm})+1$ row cabbage $(60 \mathrm{~cm} \times 50 \mathrm{~cm})$ between maize. The highest maize equivalent yield was also obtained in maize planting $(60 \mathrm{~cm} \times 20 \mathrm{~cm})+1$ row cabbage $(60 \mathrm{~cm} \times 50 \mathrm{~cm})$ followed by that of maize paired row $(150 / 37.5 \mathrm{~cm}$ $\mathrm{x} 25 \mathrm{~cm})+2$ rows cabbage $(50 \mathrm{~cm} \times 50 \mathrm{~cm})$. The highest gross return, gross margin and BCR were obtained in maize planting $(60 \mathrm{~cm} \times 20 \mathrm{~cm})+1$ row cabbage $(60 \mathrm{~cm} \times 50 \mathrm{~cm})$ followed by that of maize paired row $(150 / 37.5 \mathrm{~cm} \times$ $25 \mathrm{~cm})+2$ rows cabbage $(50 \mathrm{~cm} \times 50 \mathrm{~cm})$ and the lowest in sole sowing of maize. The overall results indicated that among the intercrop combinations maize planting $(60 \mathrm{~cm} \times 20 \mathrm{~cm})+1$ row cabbage $(60 \mathrm{~cm} \times 50 \mathrm{~cm})$ and maize paired row $(150 / 37.5 \mathrm{~cm} \times 25 \mathrm{~cm})+2$ rows cabbage $(50 \mathrm{~cm} \times 50 \mathrm{~cm})$ were found suitable for total productivity and economic return of the system.

\section{References}

Ahmed, B., D. Shabnam, S. Shabnam, M.A. Hossain and M.M. Islam. 2018. Intercropping grasspea with chilli at varying plant population. Int. J. App. Res. 4 (1): 58-61.

Ahmed, H., H. Herren, Z. R. Khan, J. A. Pickett and C. M. Woodcock. 2008. Integrated Pest Management: the push-pull approach for controlling insect pests and Weeds of cereals and its potential for other agricultural systems including animal husbandry. Philos Trans R SocLond B Biol Sci. 363(1491): 611-621.

BBS (Bangladesh Bureau of Statistics). 2015. Statistical Pocket Book of Bangladesh. Statistics and Informatics Division, Ministry of Planning, Government of the People's Republic of Bangladesh. pp.91-93.

Boras, M., N. Roukia and R. Babilie. 2006. The effect of Corn Intercropping on Autumn Potato in Terms of Productivity and Land Equivalent Ratio. Tishreen Univ. J. Studies \& Scientific Research- Biol. Sci. Series.28(1).

Bandyopadhyay, S.N. 1984. Nitrogen and water relations in grain sorghum-legume intercropping systems. Ph.D. Dissertation, Indian Agril. Res. Inst., New Delhi.

Baidoo, P.K., M.B. Mochiah and K. Apusiga. 2012. Onion as a Pest Control Intercrop in Organic Cabbage (Brassica oleracea) Production System in Ghana. Sus. Agric. Res. 1(1): 36-41. 
Khanum et al.

Dewit, C. T. and J. P. Vander Bergh. 1965. Competition between herbage plants. Neth. J. Agri. Sci. 13: 212-221.

Faruque.A., A. Hashem and A. Jahan. 1996. Productivity and profitability of potato intercropped with wheat. Bangladesh J. Bot. 25(1): 1-4.

Gomez, K.A. and A.A. Gomez. 1984. Statistical procedures for agricultural research. John Wiley and Sons, New York. pp.97-129.

Hatch, M.D. and C.R. Slack. 1998. C C $_{4}$ photosynthesis: discovery, resolution, recognition and significance. Discoveries in Plant Biology, World Scientific Publishing, Singapore. 1: 175-196.

Islam, H.M.S., R.U. Choudhury, B. Ahmed, S. Shabnam and M.M. Rahman. 2014. Adoption of Mixed Cropping in Rabi Season by the Farmers of Madaripur Sadarthana under Madaripur District. Intl. J. Buss. Soc. Sci. Res. 1(3): 168171.

Ouma, G. and P. Jerito. 2010. Sustainable horticultural crop production through intercropping: The case of fruits and vegetable crops: A review. Agric. bio. J. North America. 1(5): 1098-1105.

Quayyum, M.A., M.E. Akanda and T. Islam. 1985. Effect of intercropping maize with groundnut at varying levels of plant population and nitrogen levels, Bangladesh J. Agric. 10(3): 1-6.

Shahenuzzaman, M., R.R. Saha, B. Ahmed, J. Rahman and M. Salim. 2015. Green cob and fodder yield of sweet corn as influenced by sowing time in the hilly region. Bangladesh J. Agril. Res. 40(1): 61-69.

Talukder, A.H.M.M.R., B. Ahmed, L. Nahar, K.M.F. Hossain, J. Rahman and S.K. Paul. 2016. Enhancement of Farm productivity through intercropping of vegetables, pulse and oilseed crops with wheat at Jamuna Char area of Islampur in Jamalpur District. Int. J. Appl. Res. 2(2): 71-76.

Thayamini, H., Seran and I. Brintha. 2010. Review on Maize Based Intercropping. J. Agron. 9(3): 135-145.

Willey, R.W. 1979. Intercropping its importance and research needs. Part. 1. Competition and yield advantages. Field Crops Abst. 32(1): 1-10. 